\title{
Combining ability and heterosis for some canola characteristics sown on recommended and late planting dates using biplot
}

\author{
Hassan AMIRI OGHAN ${ }^{1 *}$, Farnaz SHARIATI ${ }^{1}$, Naser SABAGHNIA ${ }^{2}$, Bahram ALIZADEH $^{1}$, James MILLNER $^{3}$, \\ Amir Hossein SHIRANI RAD ${ }^{1}$ and Majid GHOLAMHOSEINI ${ }^{1}$
}

Received April 18, 2018; accepted July 23, 2018.

Delo je prispelo 18. aprila 2018, sprejeto 23. julija 2018.

\begin{abstract}
Canola (Brassica napus L.) is one of the most efficient oilproducing crops in arid and semi-arid regions of the world. In the current study, ten winter canola genotypes [seven genotypes as lines (Zarfam (L1), Talaye (L2), SLM046 (L3), Geronimo (L4), Modena (L5), Opera (L6) and Symbol (L7)] and three genotypes as testers [Okapi (T1), Licord (T2) and Orient (T3)] and their F1 hybrids (21 hybrids) were evaluated to determine the genetic parameters for grain yield, oil content, meal and seed glucosinolate contents under two different planting date [recommended (late September) and late planting (late October)]. According to combined analysis of variance there were significant differences among the genotypes for most studied traits. The genotype main effect and genotype $\times$ environment interaction (GGE) biplot method was used for analyzing line $\times$ tester design data. Among the lines, L5 showed high negative general combining ability (GCA) effect for meal glucosinolate content in both conditions whereas L1, L5 and L6 revealed high negative GCA effects for seed glucosinolate content in both planting date. From the results, it could be concluded that, hybridization between $\mathrm{T} 1 \times \mathrm{L} 1, \mathrm{~T} 1 \times \mathrm{L} 6$ or $\mathrm{T} 3 \times \mathrm{L} 5$ is an efficient approach to release genotypes with low seed and meal glucosinolate content. Furthermore, to develop canola cultivars with higher seed and oil yield, hybridization between $\mathrm{T} 1 \times \mathrm{L} 7$ or $\mathrm{T} 2 \times \mathrm{L} 7$ is highly recommended. Improved oil content will be achieved if $\mathrm{T} 1 \times \mathrm{L} 5, \mathrm{~T} 2 \times \mathrm{L} 5$ or $\mathrm{T} 3 \times \mathrm{L} 6$ hybrids are implemented into the breeding programs.
\end{abstract}

Key words: GGE biplot; heterosis; line $\times$ tester; polygon; grain yield; oil content

\section{IZVLEČEK}

\section{SPOSOBNOST KOMBINIRANJA IN HETEROTIČNEGA UČINKA ZA NEKATERE LASTNOSTI OLJNE OGRŠČICE SEJANE OB PRIPOROČENEM IN POZNEM TERMINU Z UPORABO BIPLOTA}

Oljna ogrščica (Brassica napus L.) je $\mathrm{v}$ sušnih in polsušnih območjih sveta ena izmed najbolj učinkovitih poljščin za proizvodnjo olja. V raziskavi je bilo ovrednoteno deset ozimnih genotipov oljne ogrščice [sedem genotipov kot linije (Zarfam (L1), Talaye (L2), SLM046 (L3), Geronimo (L4), Modena (L5), Opera (L6) in Symbol (L7)] in trije genotipi kot testerji [Okapi (T1), Licord (T2) and Orient (T3)] ter njihovi F1 križanci (21 križancev) za določitev genetskih parametrov za pridelek zrnja, vsebnost olja, vsebnost glukozinulatov $\mathrm{v}$ pogači in semenu $\mathrm{v}$ razmerah priporočene (konec septembra) in pozne setve (konec oktobra). Glede na kombinirano analizo variance so bile med genotipi značilne razlike za večino preučevanih znakov. Za analizo glavnega učinka genotipa in njegove interakcije $\mathrm{z}$ okoljem pri križancih linij in testerjev je bila uporablja metoda biplota. Med linijami je L5 pokazala zelo negativno splošno kombinacijsko sposobnost (GCA) za vsebnost glukozinulatov v pogači v obeh terminih setve, $v$ istih razmerah so imele linije L1, L5 in L6 velik negativni GCA učinek na vsebnost glukozinulatov v semenu. Iz rezultatov bi lahko zaključili, da so križanja kot so T1 $\times$ L1, T1 $\times$ L6 ali T3 $\times$ L5 učinkovit pristop za odbor genotipov $\mathrm{z}$ majhno vsebnostjo glukozinulatov v semenu in pogači. Še več, za vzgojo sort oljne ogrščice $\mathrm{z}$ večjim pridelkom semena in olja so križanja T1 $\times$ L 7 ali T2 $\times$ L7 zelo priporočena. Izboljšano vsebnost olja bi lahko dosegli,če bi bila križanja T1×L5, T2×L5 ali T3×L6 vključena v žlahniteljske programe.

Ključne besede: GGE biplot; heterozis; linija $\times$ tester; polygon; pridelek zrnja; vsebnost olja

\footnotetext{
1 Seed and Plant Improvement Institute, Agricultural Research, Education and Extension Organization (AREEO), Karaj, Iran, Postal code: +982636702369, P.O. Box: 3183969111: *corresponding author: amirioghan2014@ gmail.com

${ }^{2}$ Faculty of Agriculture, University of Maragheh, Maragheh, Iran

3 Massey University, Palmerston North, New Zealand
} 


\section{INTRODUCTION}

Canola (Brassica napus L.), a low-acid cultivar of rapeseed, is known as one of the most important edible oilseed crops across the world (Wang, 2005). Canola plays a starring role in the oilseed crops business. It has been reported that one percentage increase in canola seed oil is equivalent to 2.3 2.5 percentage increase in seed yield (Qian et al., 2009). Accordingly, a lot of effort has been put to breed high oil yield canola cultivars around the globe. It is well understood that the heterosis is an effective approach to increase crops' yield (Wang et al., 2009). A high-parent heterosis with $120 \%$ for grain yield in rapeseed was reported by Brandle and McVetty (1989). In addition, Qi et al. (2003) reported the over parent percentage of grain yield per plant was $70.24 \%(30.70-218.0 \%)$. In most of the countries, hybridization plays a key role in the development of canola cultivars (Miller, 1999; Fu, 2000). However, little is known about the heterosis and its role in oil content in canola cultivars. For instance, Shen et al. (2005) pointed out that mid-parent heterosis for seed oil content differs from $-1.55 \%$ to $7.44 \%$. Therefore, further studies on heterosis in canola and its effects on oil content are helpful.

In order to improve canola seed yield, it is essential to have certain information on the nature of both general and specific combining ability (GCA, SCA) of candidate parents, used in hybridization. Moreover understanding the nature of genes action in controlling quantitative and qualitative traits is a critical aspect of breeding programs (Velasco \& Becker, 1998). Numerous researches have been performed on combining ability and heterosis, most of these researches have shown significant effects of GCA and SCA on grain yield and oil content in canola suggesting that both additive and non-additive gene action play a crucial role in inheritance of these traits (Schierholt et al., 2001; Amiri-Oghan et al., 2009; Qian et al., 2009).

The line $\times$ tester approach is widely used in breeding both self and cross-pollinated crops to identify the most desirable parents. The crosses are chosen based on their GCA and SCA effects (Hinkelmann, 2012). On the other hand, combining ability analysis is a powerful tool to select the most desirable parental lines to release superior hybrids. The success in the hybridization programs strongly depends on the ability of the parents to perform desirable combinations (Hallauer \& Miranda, 1981). Visual exploration of GCA and SCA effects through biplot approach could be beneficial for crop breeders in identifying the most suitable parents for hybridization. The biplot analysis method, which is used to graphically depict a two-dimensional dataset, was developed by Gabriel in 1971. However, some modifications have been made in the primary biplot analysis method over the time. For instance; Yan et al. (2000) proposed a special biplot as GGE (genotype main effect and genotype $\times$ environment interaction), developed from the first two principal components (PC1 and PC2) derived from principle component analysis of environment-centered yield data, for multi-environment trials.

In a study, Yan and Hunt (2002) applied the SREG2 model for graphic analysis of diallel data using biplot method. The SREG2 model consisted of two principal components namely PC1 and PC2, derived from testercentered data, referred to as primary and secondary effects, respectively. In the line $\times$ tester data GGE biplot analysis, the "average yield" and "yield stability" are correspond to GCA and SCA of the parents, respectively (Yan et al., 2001). In other words, in the multi-environment trials data, genotypes are considered as lines and environment is considered as testers while it is reverse in the case of line $\times$ tester.

The objectives of this research were (i) to use the GGE biplot analysis for graphical interpretation of the line $x$ tester data in canola and (ii) to determine the combining abilities of some canola parents for some important quantitative and quality traits.

\section{MATERIALS AND METHODS}

All the field experiments were carried out in research station of Seed and Plant Improvement Institute (SPII), Karaj, Iran in 2009 growing season. Seven winter canola lines including 'Zarfam' (L1), 'Talaye' (L2), 'SLM046' (L3), 'Geronimo' (L4), 'Modena' (L5), 'Opera' (L6) and 'Symbol' (L7), were crossed with three winter testers including 'Okapi' (T1), 'Licord' (T2), and 'Orient' (T3), based on the line $\times$ tester crossing scheme. The obtained seeds from 21 F1 hybrids and their parents were arranged and sown in a randomized complete block design with two replicates at two different planting dates: recommended planting date $\left(29^{\text {th }}\right.$ September, 2009), and late planting date (29 ${ }^{\text {th }}$ October, 2009). Each plot consisted of four rows, $3 \mathrm{~m}$ long and $0.3 \mathrm{~m}$ apart. The distance between plants in the rows was $5 \mathrm{~cm}$, providing a plant density of 240 plants per plot. The crop was grown according to local cultural practices and with uniform fertilization and plant 
protection treatments. At maturity stages, seed yield was determined from manually harvesting two middle rows of each plot and expressed as tons per hectare. The oil quantity (seed oil content) and quality (glucosinolate content in meal and seed) were measured using $3 \mathrm{~g}$ seed collected from each plot using nuclear magnetic resonance (NMR) machine (Bruker-Biospin, Karlsruhe, Germany) and gas chromatography (GC), respectively.

The normality of data were first confirmed by Anderson and Darling (1952) normality test using MINITAB version 14 (2005) statistical software. Pooled analysis of variance for combining ability was carried out according to the model presented by Elitriby et al. (1981). High-parent heterosis was estimated using mean values and t-test was applied for its significance test. The mean values for F1 hybrids and their parents were used to develop a line $\times$ tester dataset. The dataset was used to extract the first two principal components (PCs, see below). Data for the genotype's mean were subjected to line $\times$ tester analysis to estimate GCA and SCA effects using biplot analysis. And finally the following regression model (called SREG2, Yan and Kang, 2002) was developed:

$$
\gamma_{i j}-\beta_{j}=\lambda_{1} \xi_{i 1} \eta_{j 1}+\lambda_{2} \xi_{i 2} \eta_{j 2}+\varepsilon_{i j}
$$

where $\gamma_{i j}$ is the genotypic value of the cross between line $\mathrm{i}$ and tester $\mathrm{j} ; \beta_{j}$ is the mean of all crosses sharing tester $\mathrm{j} ; \lambda_{1}$ and $\lambda_{2}$ are the singular values for the first and second principal components (PCs); $\xi_{i 1}$ and $\xi_{i 2}$ are the $\mathrm{PC} 1$ and $\mathrm{PC} 2$ eigenvectors, respectively, for line i; $\eta_{j 1}$ and $\eta_{j 2}$ are the PC1 and PC2 eigenvectors, respectively, for tester $\mathrm{j}$; and $\varepsilon_{i j}$ is the model residual. All biplots were generated using the GGE biplot software package (Yan, 2001).

\section{RESULTS AND DISCUSSION}

According to the pooled analysis of variance, there were significant differences among environments in terms of oil yield and grain yield. However in case of the treatments, significant differences were found between parents and crosses in all traits (Table 1). The parents vs crosses, which represents average heterosis, was significant in all the traits except for oil content. Lines and line $\times$ tester were found to be significant in all the traits while testers were significant only in meal and seed glucosinolate contents. There were significant differences among treatments $\times$ environments in all the traits except for oil content. The significant interactions suggest that differences among lines, testers, and crosses are not constant from one condition to another. This type of interaction is more common and inevitable in agricultural and biological investigations (Yan \& Kang, 2002).

The application of GGE biplot model demonstrated that the first two terms were relatively sufficient to explain the high proportion of variation in meal glucosinolate content in recommended and late planting dates by $80 \%$ and $85 \%$, respectively. In the polygon view of the biplot, which is formed through connecting the markers of the vertex lines, the perpendicular lines were drawn from the biplot origin to each side of the polygon and divided the biplot into few sectors. In both planting dates, there were four vertex lines for meal glucosinolate content; L1, L3, L4 and L5 lines in the recommended planting and L3, L4, L5 and L6 lines in the late planting. These vertex lines identify the lines with the highest SCA for each tester. When recommended planting date was applied, the highest SCAs were related to $\mathrm{L} 1$ and $\mathrm{T} 1$, included in that sector, L4 and T2 and L5 T3 (Fig. 1A). In case of late planting date, the highest SCAs were related to L6 and T1, included in that sector, L3 and T2 and L5 and T3 (Fig. 1B). The significant interaction between genotype and environment is a common result in studies like this project, however, this result was not found between L5 and T3. Since SCA provides an estimate for nonadditive gene action (Sprague \& Tatum, 1942), these results were in agreement with those of Rameah et al. (2003), who stated that most of the total genetic variations in meal glucosinolate content in canola were due to non-additive gene effects. 
Table 1: Combined analysis of variance for studied traits in rapeseed

\begin{tabular}{|c|c|c|c|c|c|}
\hline $\begin{array}{l}\text { Source of } \\
\text { variations }\end{array}$ & df & 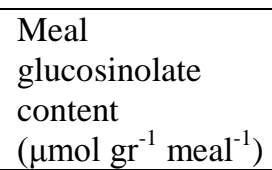 & $\begin{array}{l}\text { Seed } \\
\text { glucosinolate } \\
\text { content } \\
\left(\mu \mathrm{mol} \mathrm{gr}^{-1} \operatorname{seed}^{-1}\right)\end{array}$ & $\begin{array}{l}\text { Oil } \\
\text { content } \\
(\%)\end{array}$ & $\begin{array}{l}\text { Grain } \\
\text { yield } \\
\left(\mathrm{t} \mathrm{ha}^{-1}\right)\end{array}$ \\
\hline Environment (E) & 1 & $13.86^{\mathrm{ns}}$ & $32.73^{\mathrm{ns}}$ & $0.15^{\mathrm{ns}}$ & $55.15^{* *}$ \\
\hline Replications/E & 2 & 27.26 & 48.25 & 11.79 & 2.908 \\
\hline Treatments (G) & 30 & $155.60^{* * *}$ & $201.81^{* *}$ & $5.01^{* *}$ & $0.544^{* *}$ \\
\hline Parents (P) & 9 & $23.40^{* *}$ & $36.40^{* *}$ & $2.81^{*}$ & $0.554^{* *}$ \\
\hline P vs. Crosses (C) & 1 & $169.65^{* *}$ & $169.21^{* *}$ & $1.25^{\mathrm{ns}}$ & $1.997^{* *}$ \\
\hline Crosses (C) & 20 & $214.38^{* * *}$ & $277.88^{* *}$ & $6.19^{* * *}$ & $0.467^{* *}$ \\
\hline Lines (L) & 6 & $156.34^{* *}$ & $145.49^{* *}$ & $5.48^{* *}$ & $0.707^{* *}$ \\
\hline Testers (T) & 2 & $85.88^{* *}$ & $126.16^{* *}$ & $1.92^{\mathrm{ns}}$ & $0.081^{\mathrm{ns}}$ \\
\hline $\mathrm{L} \times \mathrm{T}$ & 12 & $264.82^{* *}$ & $369.36^{* *}$ & $7.25^{* *}$ & $0.412^{* *}$ \\
\hline $\mathrm{G} \times \mathrm{E}$ & 30 & $7.92^{* *}$ & $7.75^{*}$ & $1.20^{\mathrm{ns}}$ & $0.436^{* *}$ \\
\hline $\mathrm{P} \times \mathrm{E}$ & 9 & $2.30^{\mathrm{ns}}$ & $3.99^{\mathrm{ns}}$ & $0.53^{\mathrm{ns}}$ & $0.261^{*}$ \\
\hline$($ P vs. C) $\times E$ & 1 & $4.61^{\mathrm{ns}}$ & $7.26^{\mathrm{ns}}$ & $1.68^{\mathrm{ns}}$ & $0.195^{\mathrm{ns}}$ \\
\hline $\mathrm{C} \times \mathrm{E}$ & 20 & $10.61^{* *}$ & $9.46^{* *}$ & $1.48^{\mathrm{ns}}$ & $0.527^{* *}$ \\
\hline $\mathrm{L} \times \mathrm{E}$ & 6 & $9.86^{* *}$ & $7.07^{\mathrm{ns}}$ & $1.93^{\mathrm{ns}}$ & $0.704^{* *}$ \\
\hline $\mathrm{T} \times \mathrm{E}$ & 2 & $13.99^{* *}$ & $15.29^{*}$ & $3.27^{\mathrm{ns}}$ & $0.039^{\mathrm{ns}}$ \\
\hline $\mathrm{L} \times \mathrm{T} \times \mathrm{E}$ & 12 & $10.42^{* * *}$ & $9.69^{*}$ & $0.96^{\mathrm{ns}}$ & $0.520^{* *}$ \\
\hline Error & 60 & 2.49 & 4.26 & 1.31 & 0.113 \\
\hline
\end{tabular}

**, * and ns, stands for significant at the $1 \%$ and $5 \%$ probability level and non-significant respectively
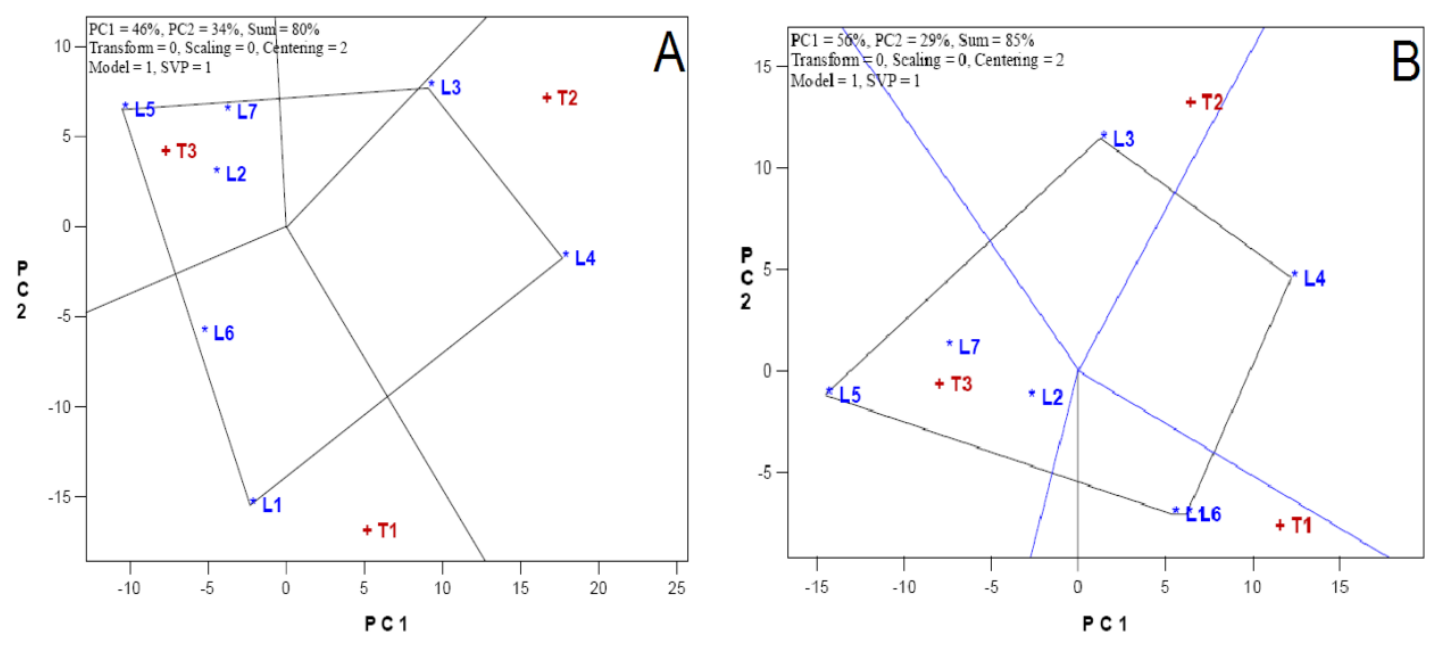

Figure 1: Polygon view of GGE biplot based on linextester data of rapeseed for meal glucosinolate content in normal (A) and late planting (B) dates

As can be seen from Fig. 1A, there is high negative GCA effect for L5 line, whereas L3 and L4 showed positive GCA effects for meal glucosinolate content in recommended planting (RP) date. The L2, L6 and L7 lines appeared to have slightly negative GCA effects, and L1 line showed no GCA effect for meal glucosinolate content in recommended planting (RP) date (Fig. 1A). From Fig. 1B, L5 line showed high negative GCA effect, whereas L4 line showed positive
GCA effects for meal glucosinolate content in late planting date. Moreover, $\mathrm{L} 7$ line indicated moderate, negative GCA effect. In addition, L1 and L6 lines showed moderate and positive GCA effects. The L2 and L3 lines had near zero GCA effect for meal glucosinolate content in late planting date (Fig. 1B). Thus, it appears that L5 line could be considered as superior combiner to develop genotypes with low meal glucosinolate content. Considering that GCA provides 
an estimate for additive gene actions (Griffing, 1956), the current results were in agreement with those of Marjanovic et al. (2007), who stated that most of the total genetic variability in meal glucosinolate content in canola were due to additive gene effects.

Biplot analysis was used to identify four distinct heterotic groups or sectors in both planting dates. Lines of each sector are suitable candidates for reaching high negative heterosis to produce genotypes with low glucosinolate content. This can be identified through original heterotic data (Table 2). The highest estimated negative heterosis for meal glucosinolate content was observed in combinations of T1 $\times$ L3, T1 $\times$ L7, T2 $\times$ L1, T2 $\times$ L6, T3 $\times$ L3 and T3 $\times$ L6, which were located in the distinct sectors in Fig. 1A and Fig. 1B. It is clear that polygon view of the biplot is a beneficial tool for detecting heterosis patterns in canola breeding materials.

The GGE biplot model described 83 and $88 \%$ of total variation in seed glucosinolate content in both planting dates, respectively. In recommended planting date, there were four vertex lines including L1, L3, L4 and L5; and in the late planting date, there were five vertex lines including L1, L3, L4, L5 and L6. Therefore, the highest SCAs were related to L1 and T1, L3 and T2, and L5 and $\mathrm{T} 3$ in recommended planting date (Fig. 2A). Regarding late planting date, the highest SCAs were related to L3 and T2, included in that sector; L5 and T3 and L6 and
T1 (Fig. 2B). Only T3 tester had different lines across two planting dates and the other testers did not indicate GE interaction.

In recommended planting date, the L1 and L6 lines showed high negative GCA effects, whereas L3 line showed positive GCA effect for seed glucosinolate content (Fig. 2A). In addition, in recommended planting date, moderate and positive GCA effects were found in L4 and L7 lines whereas, L2 and L5 lines showed no GCA effect for seed glucosinolate content (Fig. 2A). According to Fig. 2B, when it comes to late planting date, L1 and L6 lines showed high negative GCA effects, whereas L5 line showed positive GCA effects for seed glucosinolate content. Furthermore, L3 and L7 lines showed moderate and positive GCA effects, and L2 and L4 lines showed near zero GCA effect for seed glucosinolate content in late planting (Fig. 2B). Therefore, it appears that L1 and L6 lines could be considered as the good combiners to develop genotypes with low seed glucosinolate content. Similar to meal glucosinolate content, different heterotic groups can be identified from seed glucosinolate content biplots. There were four distinct groups in both planting dates. The highest negative heterosis for seed glucosinolate content was observed when $\mathrm{T} 1 \times \mathrm{L} 3, \mathrm{~T} 2 \times \mathrm{L} 1, \mathrm{~T} 2 \times \mathrm{L} 6, \mathrm{~T} 3 \times \mathrm{L} 3$, T3 $\times$ L6 6 and T3 $\times$ L 7 were combined (Table 2). The results are located in the distinct sectors in Fig. 2A and Fig. 2B. 
Hassan Amiri OGHAN et. al

Table 2: Estimates of high-parent heterosis in a line $\times$ tester experiments of rapeseed across two planting dates

\begin{tabular}{|c|c|c|c|c|c|c|c|c|}
\hline & \multicolumn{2}{|c|}{ Meal glucosinolate content } & \multicolumn{2}{|c|}{ Seed glucosinolate content } & \multicolumn{2}{|c|}{ Oil content } & \multicolumn{2}{|c|}{ Grain yield } \\
\hline & NP & LP & NP & LP & NP & LP & NP & LP \\
\hline $\mathrm{T} 1 \times \mathrm{L} 1$ & $195.1^{* * *}$ & $74.0^{* *}$ & $150.3^{* * *}$ & $102.4^{* * *}$ & $-3.1^{* * *}$ & $-4.6^{* *}$ & $21.4^{* *}$ & $-20.5^{* *}$ \\
\hline $\mathrm{T} 1 \times \mathrm{L} 2$ & $-31.0^{* *}$ & $18.5^{* *}$ & $-31.0^{* *}$ & $18.5^{* *}$ & $0.0^{\mathrm{ns}}$ & $-0.5^{\mathrm{ns}}$ & $13.6^{* *}$ & $12.3^{* *}$ \\
\hline $\mathrm{T} 1 \times \mathrm{L} 3$ & $-51.3^{* *}$ & $-55.6^{* *}$ & $-54.0^{* *}$ & $-55.6^{* *}$ & $-1.4^{\mathrm{ns}}$ & $-1.7^{\mathrm{ns}}$ & $-16.4^{* *}$ & $33.6^{* *}$ \\
\hline $\mathrm{T} 1 \times \mathrm{L} 4$ & $251.7^{* *}$ & $302.2^{* *}$ & $215.7^{* *}$ & $139.8^{* *}$ & $-4.4^{* *}$ & $-2.0^{\mathrm{ns}}$ & $-21.8^{* *}$ & $-5.9^{* *}$ \\
\hline $\mathrm{T} 1 \times \mathrm{L} 5$ & $31.1^{* *}$ & $-22.1^{* *}$ & $30.5^{* *}$ & $-22.0^{* *}$ & $1.1^{\mathrm{ns}}$ & $-2.2^{\mathrm{ns}}$ & $1.8^{* *}$ & $5.8^{* *}$ \\
\hline $\mathrm{T} 1 \times \mathrm{L} 6$ & $78.8^{* * *}$ & $74.4^{* *}$ & $136.2^{* * *}$ & $71.2^{* *}$ & $-1.8^{\mathrm{ns}}$ & $-2.5^{\mathrm{ns}}$ & $23.9^{* *}$ & $9.1^{* *}$ \\
\hline $\mathrm{T} 1 \times \mathrm{L} 7$ & $-64.1^{* *}$ & $-39.8^{* *}$ & $-64.1^{* *}$ & $-39.8^{* *}$ & $-0.9^{\mathrm{ns}}$ & $-0.4^{\mathrm{ns}}$ & $26.7^{* *}$ & $34.1^{* *}$ \\
\hline $\mathrm{T} 2 \times \mathrm{L} 1$ & $-55.9^{* * *}$ & $-57.0^{* *}$ & $-55.9^{* *}$ & $-50.0^{* * *}$ & $0.8^{\mathrm{ns}}$ & $1.4^{\mathrm{ns}}$ & $2.8^{* *}$ & $-13.1^{* * *}$ \\
\hline $\mathrm{T} 2 \times \mathrm{L} 2$ & $-21.2^{* *}$ & $-33.4^{* *}$ & $-21.2^{* *}$ & $-40.3^{* *}$ & $-1.3^{\mathrm{ns}}$ & $1.7^{\mathrm{ns}}$ & $-23.0^{* *}$ & $-18.4^{* *}$ \\
\hline $\mathrm{T} 2 \times \mathrm{L} 3$ & $73.5^{* *}$ & $63.1^{* *}$ & $64.2^{* *}$ & $63.0^{* *}$ & $-0.8^{\mathrm{ns}}$ & $-2.3^{\mathrm{ns}}$ & $8.7^{* *}$ & $-0.2^{\mathrm{ns}}$ \\
\hline $\mathrm{T} 2 \times \mathrm{L} 4$ & $268.2^{* *}$ & $189.4^{* *}$ & $198.7^{* *}$ & $108.7^{* *}$ & $-4.7^{* *}$ & $-2.0^{\mathrm{ns}}$ & $-26.0^{* *}$ & $-3.6^{* * *}$ \\
\hline $\mathrm{T} 2 \times \mathrm{L} 5$ & $14.6^{* *}$ & $-43.6^{* *}$ & $14.6^{* *}$ & $-13.4^{* *}$ & $1.9^{\mathrm{ns}}$ & $2.1^{\mathrm{ns}}$ & $-5.3^{* *}$ & $-23.6^{* *}$ \\
\hline $\mathrm{T} 2 \times \mathrm{L} 6$ & $-58.5^{* *}$ & $-56.6^{* *}$ & $-58.5^{* *}$ & $-56.6^{* *}$ & $5.2^{* *}$ & $4.7^{* *}$ & $-6.5^{* *}$ & $-13.3^{* *}$ \\
\hline $\mathrm{T} 2 \times \mathrm{L} 7$ & $-4.3^{\mathrm{ns}}$ & $-16.7^{* *}$ & $8.2^{* *}$ & $-1.4^{\mathrm{ns}}$ & $-0.4^{\mathrm{ns}}$ & $-4.2^{* *}$ & $42.4^{* *}$ & $-20.8^{* *}$ \\
\hline $\mathrm{T} 3 \times \mathrm{L} 1$ & $-26.3^{* *}$ & $-53.5^{* *}$ & $-26.2^{* *}$ & $-45.9^{* *}$ & $2.1^{*}$ & $-0.7^{\mathrm{ns}}$ & $-11.5^{* *}$ & $-15.9^{* * *}$ \\
\hline $\mathrm{T} 3 \times \mathrm{L} 2$ & $-46.0^{* * *}$ & $-29.6^{* *}$ & $-43.9^{* *}$ & $-40.9^{* *}$ & $1.4^{\mathrm{ns}}$ & $-2.5^{\mathrm{ns}}$ & $28.8^{* *}$ & $28.9^{* *}$ \\
\hline $\mathrm{T} 3 \times \mathrm{L} 3$ & $-75.2^{* * *}$ & $-64.8^{* *}$ & $-76.5^{* *}$ & $-57.8^{* *}$ & $3.3^{* *}$ & $2.3^{\mathrm{ns}}$ & $1.0^{*}$ & $21.9^{* *}$ \\
\hline $\mathrm{T} 3 \times \mathrm{L} 4$ & $-22.3^{* *}$ & $5.0^{*}$ & $-22.4^{* *}$ & $-11.9^{* *}$ & $0.4^{\mathrm{ns}}$ & $-2.9^{*}$ & $-23.6^{* *}$ & $-2.6^{* * *}$ \\
\hline $\mathrm{T} 3 \times \mathrm{L} 5$ & $338.4^{* *}$ & $248.1^{* *}$ & $270.4^{* *}$ & $192.3^{* *}$ & $-5.6^{* *}$ & $-9.7^{* *}$ & $15.8^{* *}$ & $1.4^{* *}$ \\
\hline $\mathrm{T} 3 \times \mathrm{L} 6$ & $-23.5^{* * *}$ & $-63.3^{* *}$ & $-27.8^{* *}$ & $-63.3^{* *}$ & $4.1^{* *}$ & $6.8^{* *}$ & $38.9^{* *}$ & $5.8^{* *}$ \\
\hline $\mathrm{T} 3 \times \mathrm{L} 7$ & $-23.2^{* *}$ & $47.0^{* *}$ & $-23.2^{* *}$ & $7.2^{* * *}$ & $4.8^{* *}$ & $0.1^{\mathrm{ns}}$ & $14.9^{* *}$ & $4.7^{* *}$ \\
\hline SE & 1.67 & 1.48 & 2.05 & 2.08 & 1.01 & 1.27 & 0.40 & 0.26 \\
\hline
\end{tabular}

NP: Normal planting; LP: Late planting

**,* and $^{\mathrm{ns}}$, stands for significant at the $1 \%$ and $5 \%$ probability level and non-significant respectively 

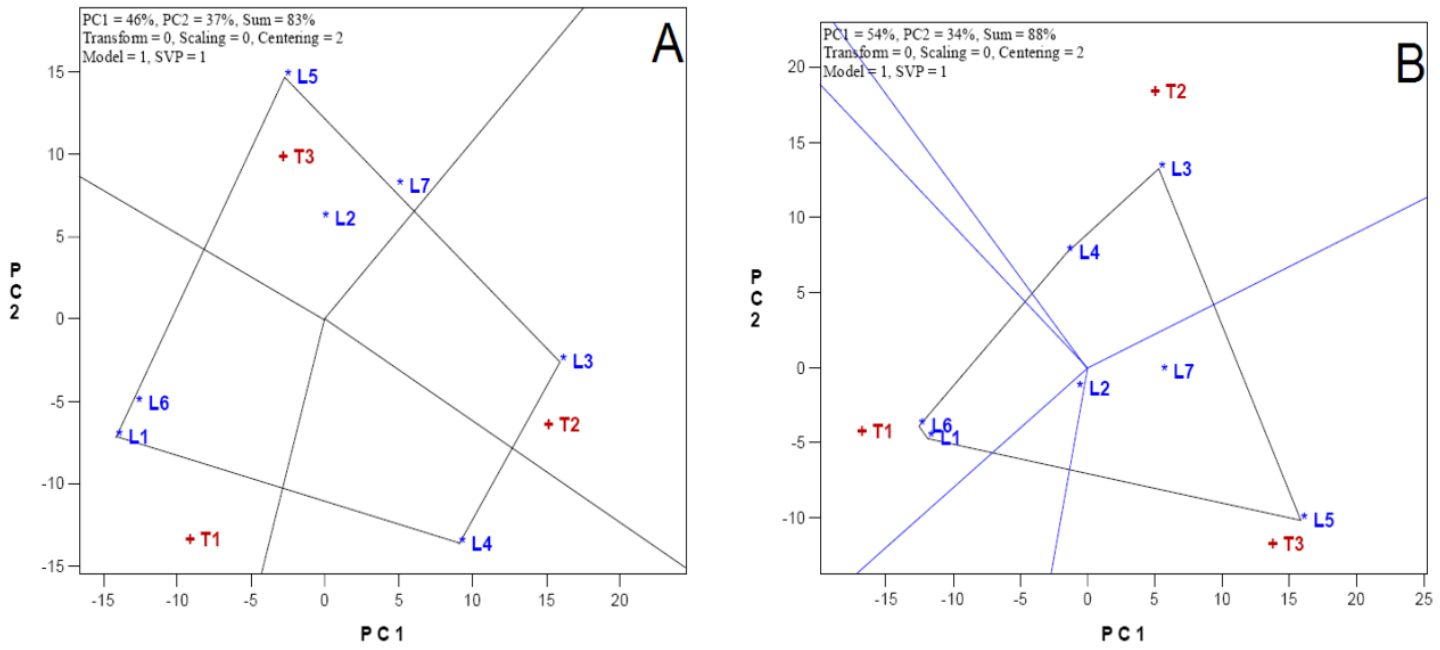

Figure 2: Polygon view of GGE biplot based on linextester data of rapeseed for seed glucosinolates content in normal (A) and late planting (B) dates

According to the oil content GGE biplot model, the first two components explained 90 and $89 \%$ of total variation, thus it seems to be sufficient as reducing the data dimensions. In the polygon view of the biplot there were four vertex lines in both planting dates, L4, L5, L6 and L7 lines in recommended planting date and L3, L5, L6 and L7 lines in late planting date. These vertex lines identify the lines with the highest SCA for each tester. In recommended planting date, the highest SCAs were related to $\mathrm{L} 5$ and $\mathrm{T} 1$, included in that sector, and $\mathrm{T} 2$ and L6 and T3 (Fig. 3A). In late planting date, the highest SCAs were related to L5 and T1, included in that sector; L6 and T2 and L6 and T3 (Fig. 3B). It is clear that there is $\mathrm{G} \times \mathrm{E}$ interaction in combination of each line with $\mathrm{T} 2$ tester for oil content (Fig. 3). Similar results emphasizing the importance of SCA effects in canola have already been reported by Marinković and Marjanović-Jeromela (2004) and Sabaghnia et al. (2010).

In recommended planting date, L5 line showed high positive GCA effect, whereas L4 line showed negative GCA effect for oil percentage. In addition, in the same planting date, L6 line indicated moderate and positive GCA effect, L7 line showed moderate and negative GCA effect, and L1, L2 and L3 lines revealed near zero
GCA effect for oil percentage (Fig. 3A). Fig. 3B indicates that L6 line has high positive GCA effect, whereas L5 and L7 lines have negative GCA effect for oil percentage in late planting date. The results indicated that L1 and L3 lines have moderate and positive GCA effect, L2 line has moderate and negative GCA effect, and L4 line has no GCA effect for oil percentage in late planting date (Fig. 3B). Therefore, it seems that L6 line can be considered as an appropriate combiner for improving of oil percentage in canola seeds. A significant relationship between the GCA and hybrid performance in terms of oil content in canola has been reported by Qian et al. (2007), indicating possibility of hybrid performance prediction by GCA. Therefore, it appears that some parents, such as, L5 and L6 are able to produce hybrids with higher oil content. Different heterotic groups could be identified using biplot polygon. Lines located in each sector are known as appropriate candidates to be crossed with related testers to achieve high positive heterosis and high oil percentage in the seeds. According to table 2, the highest positive heterosis appeared in combinations of $\mathrm{T} 2 \times \mathrm{L} 6, \mathrm{~T} 3 \times \mathrm{L} 6$ and $\mathrm{T} 3 \times \mathrm{L} 7$ (Fig. $3 \mathrm{~A})$, and combinations of T $2 \times$ L 6 and T3 $\times$ L6 (Fig. 3B), which were located in the same sectors in the biplots. 

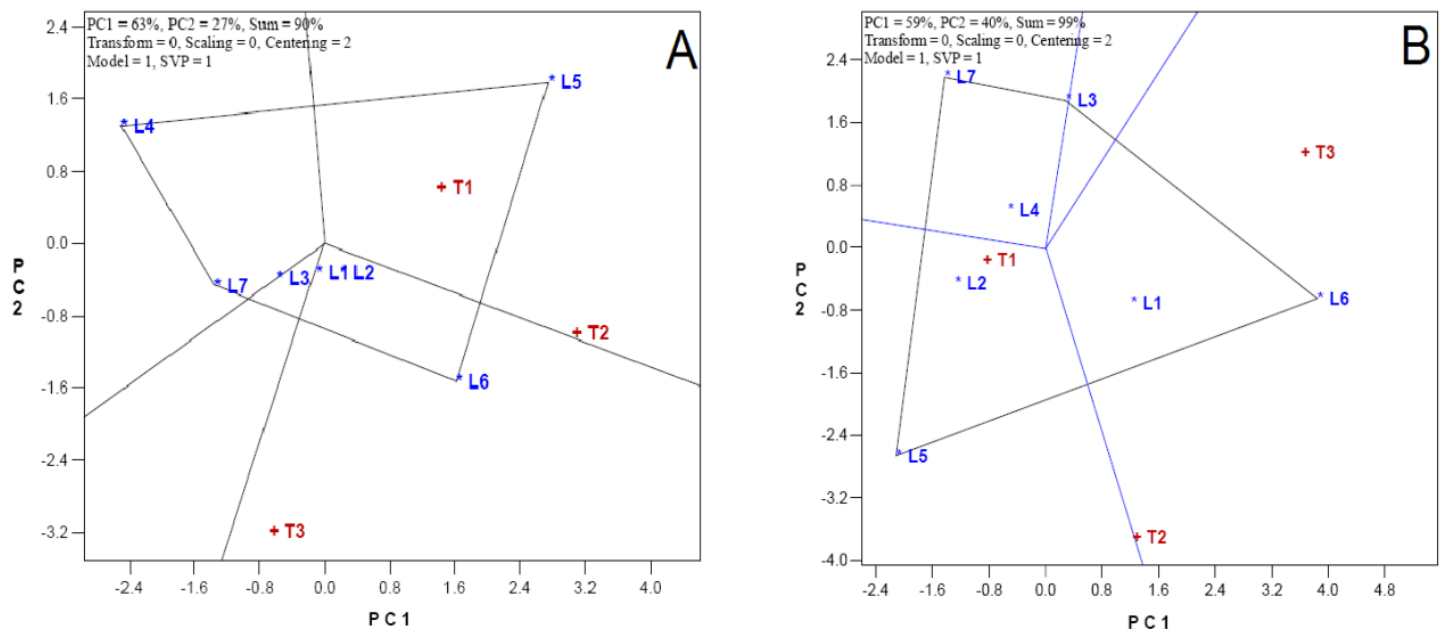

Figure 3: Polygon view of GGE biplot based on line $\times$ tester data of rapeseed for oil percent in normal (A) and late planting (B) dates

The application of GGE biplot model revealed that the first two components were relatively sufficient and explained 88 and $91 \%$ of total variation in grain yield data for both planting dates. In the polygon view of the biplot, there were five vertex lines (L1, L2, L3, L4 and L7 lines) for grain yield in recommended planting date and six lines (L1, L2, L3, L4, L5 and L7) in late planting date. In late planting, L1 line showed the highest SCA with T1 tester, which were located in the same sector; L7 line showed the highest SCA with T2 tester and L3 line showed the highest SCA with T3 tester (Fig. 4A). In late planting date, L7 line indicated the highest SCA with T1 tester included in that sector; L2 line showed the highest SCA with T2 tester and L3 line showed the highest SCA with T3 tester (Fig. 4B). It is clear that there is $\mathrm{G} \times \mathrm{E}$ interaction in this dataset, nevertheless, this interaction was not observed in combination of L3 and T3 (Fig. 4).

From the results, the L3 and L7 lines showed high positive GCA effect, whereas L2 and L4 line indicated negative GCA effect in terms of grain yield in recommended planting date. In addition, L1 Line showed moderate and positive GCA effect, and L5 and L6 lines showed moderate and negative GCA effects in terms of grain yield in recommended planting date (Fig. 4A). Fig. 5B indicates that L7 line has high positive GCA effect; however L1 and L4 lines have negative GCA effect for grain yield in late planting date. Moreover, L3 and L5 lines indicated moderate and positive GCA effect, and L2 line showed moderate and negative GCA effect. Furthermore, L6 line showed near zero GCA effect for grain yield in late planting date (Fig. 4B). Therefore, it seems that L7 line can be used as the promising combiner for improving high grain yield genotypes. These findings for GCA effects for grain yield are in agreement with Thakur and Sagwal (1997) who reported similar GCA effects for grain yield. 

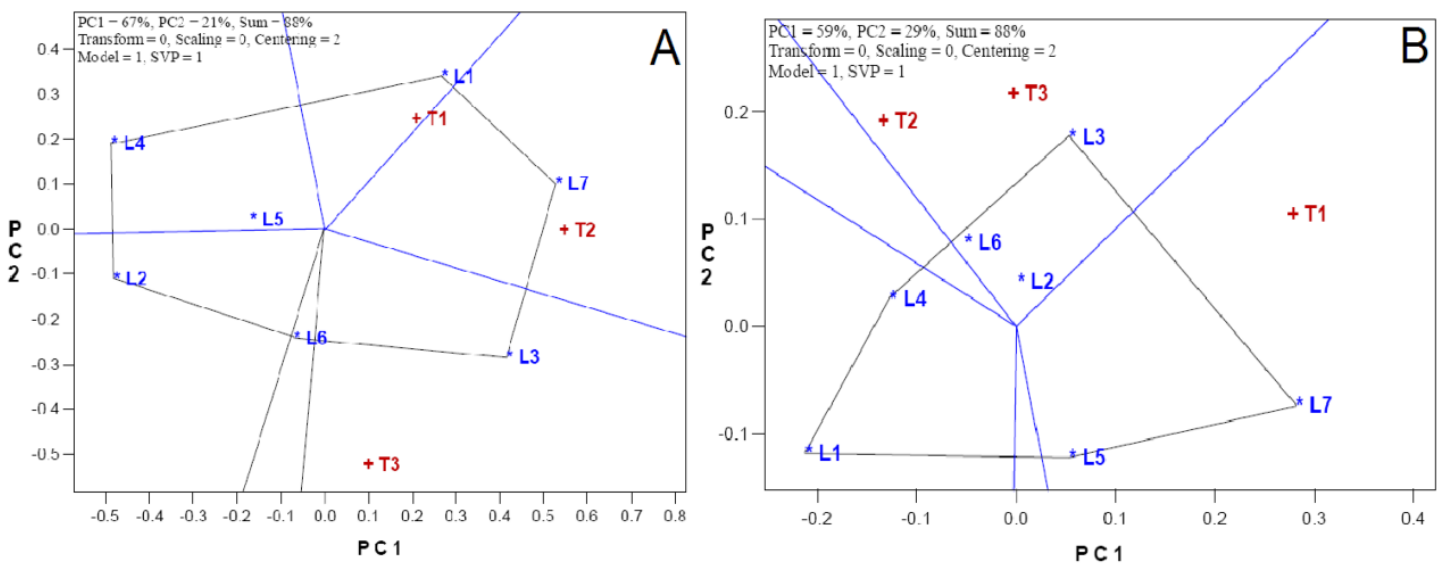

Figure 4: Polygon view of GGE biplot based on line $\times$ tester data of oilseed rape for grain yield in normal (A) and late planting (B) dates

The lines located in each sector are known as high potential candidates to be crossed with correspondent testers to gain high positive heterosis in breeding program to produce high oil yield genotypes. The highest positive heterosis values (Table 2) were observed in combinations of $\mathrm{T} 1 \times \mathrm{L} 1, \mathrm{~T} 1 \times \mathrm{L} 6, \mathrm{~T} 1 \times \mathrm{L} 7$, $\mathrm{T} 2 \times \mathrm{L} 7, \mathrm{~T} 3 \times \mathrm{L} 2$ and $\mathrm{T} 3 \times \mathrm{L} 6$, as indicated in Fig. $4 \mathrm{~A}$, and in combinations of $\mathrm{T} 1 \times \mathrm{L} 3, \mathrm{~T} 1 \times \mathrm{L} 7, \mathrm{~T} 3 \times \mathrm{L} 2$ and $\mathrm{T} 3 \times \mathrm{L} 3$ in Fig. 3B, which were located in the same sectors in the biplots. Multivariate statistical methods such as GGE biplot have been introduced to explore the multidirectional aspects of data and to extract more information from interaction components. The GGE facilitates clustering of lines and testers into more cohesive groups based on the biological understanding of the $\mathrm{L} \times \mathrm{T}$ interaction. Identifying superior lines with favorable GCA and SCA effects is another importance of the method (Yan \& Hunt, 2002). Sub-grouping of testers by the GGE method would be useful for selecting lines, because it helps researchers to exploit the interactions among lines and the subsets of testers (Yan \& Kang, 2002). Application of GGE biplot is preferred for several reasons: (i), biplots are easy to use and to interpret, (ii), knowing GCA, SCA, and identifying heterotic groups may enhance our understanding to discover important patterns within the data and (iii), other information such as the best mating partner for each parent and groups of similar parents can be graphically visualized to rapid identification of suitable parents and crosses for further investigation.

\section{CONCLUSIONS}

Finally, it can be concluded that, to release low seed or meal glucosinolate genotypes, combinations of $\mathrm{T} 1 \times \mathrm{L} 1$, $\mathrm{T} 1 \times \mathrm{L} 6$ and T3 $\times$ L5 should be taken into account as preferential materials. Moreover, combinations of $\mathrm{T} 1 \times \mathrm{L} 7$ and $\mathrm{T} 2 \times \mathrm{L} 7$ to release high grain yield genotypes and combinations of $\mathrm{T} 1 \times \mathrm{L} 5, \mathrm{~T} 2 \times \mathrm{L} 5$ and T3 $\times \mathrm{L} 6$ to increase oil content in genotypes are suggested. With a few exceptions, all the studies showed presence of significant GCA and SCA effects for grain yield and oil content, indicating that both additive and non-additive gene action are involved in the inheritance of these characteristics. The current results also revealed that most of the characteristics were controlled by both additive and non-additive of gene action so that selection in promising hybrids could be used in hybrid rapeseed development with high oil yield. Moreover, simple phenotypic selection in high performance hybrids can also be effective in segregating generations. The presence of heterosis for the traits of interest indicates existence of the genetic potential for increasing grain yield by identifying heterotic groups and evaluating parents for their combining ability. Finally, the results indicated that both oil content and grain yield in canola, as the most important parameters for industrial use, can be improved.

\section{ACKNOWLEDGEMENT}

The authors gratefully acknowledge the financial support of the Seed and Plant Improvement Institute
(SPII) and appreciate the valuable advice provided by Dr. Davood Roodi and Dr. Bahram Masoodi. 


\section{FUNDING SOURCES}

This work was supported by the Seed and Plant Improvement Institute (SPII), Karaj [Project numbers 203-03-88184].

\section{REFERENCES}

Amiri Oghan, H., Fotokian, M.H., Javidfar, F., Alizadeh, B. (2009). Genetic analysis of grain yield, days to flowering and maturity in oilseed rape (Brassica napus L.) using diallel crosses. International Journal of Plant Production, 3(2), 1926.

Anderson, T. W., Darling, D. A. (1952). Asymptotic theory of certain goodness-of-fit criteria based on stochastic processes. The Annals of Mathematical Statistics, 23(2), 193-212. doi:10.1214/aoms/1177729437

Brandle, J.E., McVetty, P.B.E. (1989). Heterosis and combining ability in hybrids derived from oilseed rape cultivars and inbred lines. Crop Science, 29, 1191-1195. doi:10.2135/cropsci1989.0011183X002900050020 $\mathrm{x}$

Brandle, J.E., McVetty, P.B.E. (1990). Geographic diversity, parental selec $\neg$ tion, and heterosis in oilseed rape. Canadian Journal of Plant Science, 70, 935-940. doi:10.4141/cjps90-115

Elitriby, H.A., Selim, A.R., Shehata, A. H. (1981). Genotype $\times$ environment interaction from combining ability estimates in maize (Zea mays L.). Egyptian Journal of Genetics and Cytology, 10, 175-186.

Fu, T. D. (2000) . Breeding and Utilization of Rapeseed Hybrid (second edition). Wuhan: Hubei Sci. and Technol. Press.

Goffman, F.D., Becker, H.C. (2001). Diallel analysis for Tocopherol content in seeds of rapeseed. Crop Science, $\quad 41, \quad 1072-1079$. doi:10.2135/cropsci2001.4141072x

Griffing, B. (1956). Concept of general and specific combining ability in relation to diallel systems. Australian Journal of Biological Sciences, 9, 463493. doi:10.1071/BI9560463

Hallauer, A.R., Miranda, F.J.B. (1981). Quantitative Genetics in Maize Breeding. Iowa State Uni. Press, Ames. Iowa. USA.

Hinkelmann, K. (2012). Design and Analysis of Experiments, Special Designs and Applications. Wiley Series in Prob. and Stat., London, UK. doi:10.1002/9781118147634
Krzymanski, J., Pietka, T., Krotka, K. (1994). Combining ability and het $\neg$ erosis in diallel crosses of double low winter oilseed rape II. F1 and F2 generations. Oilseed Crops, 15, 21-32.

Marinković, R., Marjanović-Jeromela, A. (2004). Combining ability in some varieties of winter oil rape (Brassica napus L.). Biotechnology \& Biotechnological Equipment, 18, 110-114. doi:10.1080/13102818.2004.10819239

Marjanović-Jeromela, A., Marinković, R., Miladinović, A.D. (2007). Combining abilities of rapeseed (Brassica napus L.) varieties. Genetics, 39, 53-62. doi:10.2298/GENSR0701053M

Miller, J.F. (1999). Oilseeds and heterosis. In J.G. Coors and S. Pandey (ed.) The genetics and exploitation of heterosis in crops. ASA, CSSA, and SSSA. Madison, WI. p. 399-404.

Qi, C.K., Pu, H.M., Zhang, J. F., Fu, S.Z., Chen, X.J., Gao, J.Q. (2003). Analysis of Heterosis of Seed Yield and Its Components of Inter-varietal Cross in Brassica napus L. Jiangsu Journal of Agricultural Sciences, 19, 145-150.

Qian W., Li, Q., Noack, J., Sass, O., Meng, J., Frauen, M., Jung, C. (2009). Heterotic patterns in rapeseed (Brassica napus L.): II. Crosses between European winter and Chinese semi-winter lines. Plant Breeding, 128 (5), 466-470. doi:10.1111/j.14390523.2008.01597.x

Qian, W., Sassm, O., Meng, J., Li, M., Frauen, M., Jung, C. (2007). Heterotic patterns in rapeseed (Brassica napus L.): I. Crosses between spring and Chinese semi-winter lines. Theoretical and Applied Genetics, 115, 27-34. doi:10.1007/s00122-0070537-x

Rameah, V., Rezai, A., Saeidi, G. (2003). Estimation of genetic parameters for yield, yield components and glucosinolate in rapeseed (Brassica napus L.). Journal of Agricultural Science and Technology, 5, 143-151.

Sabaghnia, N., Dehghani, H., Alizadeh, B., Moghaddam, M. (2010). Heterosis and combining ability analysis for oil yield and its components in rapeseed. Australian Journal of Crop Science, 4, 390-397. 
Sabaghnia, N., Dehghani, H., Alizadeh, B., Moghaddam, M. (2011). Yield analysis of rapeseed (Brassica napus L.) under water-stress conditions using GGE biplot methodology. Journal of Crop Improvement, 25, 26-45. doi:10.1080/15427528.2011.521919

Schierholt, A., Rücker, B., Becker, H.C. (2001). Inheritance of high oleic acid mutations in winter oilseed rape (Brassica napus L.). Crop Science, 41, 1444-1449. doi:10.2135/cropsci2001.4151444x

Shen, J.X., Fu, T.D., Yang, G.S., Ma, C.Z., Tu, J.X. (2005). Genetic analysis of rapeseed self incompatibility lines reveals significant heterosis of different patterns for yield and oil content traits. Plant Breeding, 124, 111-116. doi:10.1111/j.14390523.2004.01069.x

Sprague, G.F., Tatum, L.A. (1942). General vs specific combining ability in single crosses of corn. Agronomy Journal, 34, 923-932. doi:10.2134/agronj1942.00021962003400100008x

Thakur, H.L., Sagwal, J.C. (1997). Heterosis and combining ability in oilseed rape (Brassica napus L.). The Indian Journal of Genetics and Plant Breeding, 57, 163-167.

Velasco, L., Becker, H.C. (1998). Analysis of total glucosinolate content and individual glucosinolates in Brassica spp. By near-infrared reflectance spectroscopy. Plant Breeding, 117, 97-102. doi:10.1111/j.1439-0523.1998.tb01459.x
Wang, H.Z. (2005). The potential problems and strategy for the development of biodiesel using oilseed rape. Chinese Journal of Oil Crop Sciences., 27, 74-76.

Wang, H.Z., Lui, G.H., Wang, X.F., Liu, J., Yang, Q., Hua, W. (2009). Heterosis and breeding of high oil content in rapeseed (Brassica napus L.). 16th Aust. Res. Assem. on Brassicas. Ballarat Victoria.

Yan, W. (2001). GGE biplot- A Windows application for graphical analysis of multienvironment trial data and other types of two-way data. Agronomy Journal, 93, 1111-1118. doi:10.2134/agronj2001.9351111x

Yan, W., and Hunt, L.A. (2002). Biplot analysis of diallel data. Crop Science, 42, 21-30. /doi:10.2135/cropsci2002.0021

Yan, W., Kang, M.S. (2002). GGE Biplot Analysis: A Graphical Tool for Breeders, Geneticists, and Agronomists. CRC Press, Boca Raton, FL. doi:10.1201/9781420040371

Yan, W., Hunt, L.A., Sheng, Q., Szlavnics, Z. (2000). Cultivar evaluation and mega-environment investigation based on the GGE biplot. Crop Science, 40(3), 597-605. doi:10.2135/cropsci2000.403597x

Yan, W., Cornelius, P. L., Crossa, J., Hunt, L. A. (2001). Two types of GGE biplots for analyzing multi-environment trial data. Crop Science, 41(3), 656-663. Updated information on GGE Biplot is available online at http://www.ggebiplot.com doi:10.2135/cropsci2001.413656x 